\title{
Rehabilitation of oropharyngeal dysphagia in children with cerebral palsy: A systematic review of the speech therapy approach
}

\author{
Gisela Carmona Hirata', Rosane Sampaio Santos². \\ 1) Orofacial Motricity and Dysphagia Specialist - Speech Therapist. \\ 2) Masters in Comunication Disorders. Professor of Speech Language Pathology Undergraduate Program at Tuiuti University of Parana and Coordinator of Orofacial Motricity \\ and Voice Graduate Programs. \\ Institution: Universidade Tuiutí do Paraná - UTP. \\ Curitiba / PR - Brazil. \\ Mailing address: Gisela C. Hirata - Rua Bento Viana, 947 - Apto. 1802 - Curitiba / PR - Brazil - Zip code: 80240-110 - E-mail: giselahirata@yahoo.com.br \\ Article received in November 21, 2011. Article approved in March 18, 2012.
}

\section{SUMMARY}

Introduction: There are an estimated 30,000-40,000 new cases of cerebral palsy per year in Brazil. Motor disorders caused by cerebral palsy can lead to dysphagia as they may alter the preparatory, oral, pharyngeal, and esophageal phases.

Aim: To identify existing rehabilitation methods of swallowing disorders in cerebral palsy, with emphasis on the pursuit of research using the Bobath concept, the Castillo Morales concept, oral sensorimotor therapy, and continuing education.

Summary of the findings: We performed a systematic review of the medical and speech therapy literature on the rehabilitation of oropharyngeal dysphagia in children with cerebral palsy spanning 1977-2010 and from all languages and nations. Among the 310 articles retrieved, only $22(7.09 \%)$ addressed therapeutic rehabilitation of oropharyngeal dysphagia in children with cerebral palsy. Of the 22 reports, 12 (54.5\%) were from Canada, 3 (13.6\%) were from Japan, 2 (9\%) were from Brazil, 2 (9\%) were from Germany, 1 (4.5\%) was from the USA, 1 (4.5\%) was from the United Kingdom, and 1 (4.5\%) was from Poland. Of these reports, $63.6 \%$ used oral sensorimotor therapy as a therapeutic method, $36.3 \%$ reported continuing education as a therapeutic approach, and only 18.1\% and 9\% used the Bobath concept and Castillo Morales concept, respectively.

Conclusion: Even with a constantly increasing cerebral palsy population, few studies include (re)habilitation in the treatment of oropharyngeal dysphagia in these children.

Keywords: cerebral palsy, deglutition disorders, rehabilitation.

\section{INTRODUCTION}

Cerebral palsy is defined as a development and posture disorder due to a defect or lesion of the immature brain. The injury is not progressive and weakens muscular coordination in different ways, resulting in the inability of a child to maintain posture and perform normal movements (1).

The prevalence of moderate and severe cases of cerebral palsy is $1.5-2.5$ per 1000 live births $(2,3)$. There are an estimated 30,000-40,000 new cases of cerebral palsy per year in Brazil (4).

Motor disorders caused by cerebral palsy can lead to dysphagia as they may alter the preparatory, oral, pharyngeal, and esophageal phases. Normal primitive reflexes such as bite, suck, swallow, and the absence of tongue lateralization, among others, change and interfere with other responses such as chewing, oral control, and swallowing of bolus (5).

Recent studies indicate that dysphagia is categorically related to the severity of motor damage caused by cerebral palsy. The study of Cauis et al. (2008) showed that 99\% of 166 children with severe cerebral palsy and intellectual disability evaluated had some degree of dysphagia. More alarming was the fact that $76 \%$ of the children had moderate to severe dysphagia, and 15\% had profound dysphagia (receiving nil by mouth) (6). The study by Silva et al. (2006) observed that $80 \%$ of children with quadrispastic cerebral palsy and $67 \%$ of children with athetosis aspirated food during swallowing clinical assessment and videofluoroscopy (7).

The higher morbidity and mortality associated with cerebral palsy are related to respiratory compromise, manifested by recurrent aspiration pneumonia, airway colonization by pathogenic bacteria, evolution of bronchiectasis, and disordered breathing during sleep (8).

Some concepts and methods are well known in cerebral palsy rehabilitation, such as the Bobath concept, the Castillo Morales concept, oral sensorimotor therapy, and continuing education.

The Bobath concept is based on 2 principles: the 
inhibition or suppression of abnormal tonic reflex activity responsible for patterns of hypertonia, and the facilitation of normal reactions and highly integrated postural control and balance in their own sequence of development, progressing to specialized activities (1).

The Castillo Morales concept is based on the importance of function and not only the movement itself, relating each part of the oral complex and turning them into a dynamic system through coordinated activities (9). This concept makes use of functional jaw orthopedics through the palatine plate (9).

Speech therapy includes orofacial sensory motor exercises aimed at direct and indirect improvements in strength, mobility, and sensitivity of the structures involved in the process of sucking, swallowing, and masticating (10). The objective of using these techniques (10) and the use of intraoral prostheses (11) is the restoration of efficient swallowing or, in severe cases, preventing or minimizing intraoral hypersensitivity.

Continuing education is based on promoting the formation of a caregiver or the patient himself as a chief instrument of rehabilitation, aimed at the patient's motor functional independence. It uses guidelines and dysphagia education programs (12).

The objective of this study was to identify existing rehabilitation methods for swallowing disorders in cerebral palsy, with emphasis on the pursuit of studies that used the Bobath concept, the Castillo Morales concept, oral sensorimotor therapy, and continuing education.

\section{METHOD}

We performed a systematic review of the medical and speech therapy literature on the rehabilitation of oropharyngeal dysphagia in children with cerebral palsy spanning 1977-2010 and from all languages and nations. This review screened the MEDLINE, LILACS, Cochrane, SciELO, and PubMed databases to search for relevant references, crossing the following keywords: Rehabilitation, Cerebral Palsy, Deglutition Disorders, Treatment. From these results, we excluded articles that did not refer to speech-language therapy for oropharyngeal dysphagia in cerebral palsy, and items that were repeated between searches. The date of publication criterion was not used as an exclusion parameter in this research. Articles addressing speech therapy for oropharyngeal dysphagia in individuals with cerebral palsy were analyzed according to the nationality of the journal and therapeutic method used for the rehabilitation of dysphagia.

\section{RESULTS AND DISCUSSION}

We retrieved 408 articles, but included in the survey only 310 non-repeated articles. Among the 310 articles, only $22(7.09 \%)$ addressed the role of speech therapy in oropharyngeal dysphagia in children with cerebral palsy (Table 1).

Of the 22 studies, 12 (54.5\%) were from Canada, 3 (13.6\%) were from Japan, 2 (9\%) were from Brazil, 2 (9\%) were from Germany, 1 (4.5\%) was from the USA, 1 (4.5\%) was from the United Kingdom, and 1 (4.5\%) was from Poland.

Of these 22 studies, $63.6 \%$ used oral sensorimotor therapy as a therapeutic method, $36.3 \%$ reported continuing education as a therapeutic approach, and only $18.1 \%$ and 9\% used the Bobath method and Castillo Morales method, respectively (Table 2 ).

The 2 articles that mentioned research using the method of Rodolfo C. Morales were German, dated 1987 and 1990, and reported the use of palatal plates proposed in the Castillo Morales concept (13-14).

Of the Canadian studies, $83 \%$ used oral sensorimotor therapy as the therapeutic method.

We retrieved a review article on the oral sensorimotor approach in children with cerebral palsy with moderate dysphagia reporting that the effectiveness of this intervention was, on average, 15\% above the level of maturation of the child, and was limited to maintaining growth and not improving normal weight gain for age; thus, the authors considered the use of feeding tubes to promote more adequate nutrition (15).

Except for Germany, all other countries reported on continuing education, but only 2 used this therapeutic method as the only approach. Other studies reported the use of continuing education concurrent with other strategies. In general, these articles mentioned the guidance of parents/caregivers through changes in posture, utensils, volume, and food consistency (16-17-18-19), and changes in posture and food texture according to the results of a swallowing study by videofluoroscopy (20).

The Bobath concept was mentioned in only 2 articles, both Brazilian, and only as a method of overall handling of the child, let alone its contribution as a therapeutic method and evaluation of the oral complex. The therapeutic methodology emphasized in these studies was oral sensorimotor therapy using extra- and intraoral stimulation (16-17). Continuing education guidance of 
Table I. Publications found.

\begin{tabular}{|c|c|c|c|c|c|c|}
\hline $\begin{array}{l}\text { Crossing of } \\
\text { keywords }\end{array}$ & $\begin{array}{l}\text { Dysphagia + } \\
\text { Cerebral Palsy }\end{array}$ & $\begin{array}{l}\text { Dysphagia + } \\
\text { Rehabilitation }\end{array}$ & $\begin{array}{l}\text { Deglutition } \\
\text { Disorders + } \\
\text { Cerebral Palsy }\end{array}$ & $\begin{array}{l}\text { Dysphagia + } \\
\text { Treatment + } \\
\text { CerebralPalsy }\end{array}$ & Total & $\begin{array}{l}\text { Total } \\
\text { no } \\
\text { Repetitions }\end{array}$ \\
\hline $\begin{array}{l}\text { Total } \\
\text { Addressing }\end{array}$ & 5 & 6 & 202 & 157 & 370 & 310 \\
\hline Speech Therapy & 2 & 0 & 15 & 20 & 37 & 22 \\
\hline
\end{tabular}

Source: The author.

Table 2. Methods used in speech therapy rehabilitation for oropharyngeal dysphagia in children with cerebral palsy.

\begin{tabular}{lllll}
\hline BobathMethod & $\begin{array}{l}\text { Castillo Morales } \\
\text { Method }\end{array}$ & $\begin{array}{l}\text { OralSensorimotor } \\
\text { Therapy }\end{array}$ & ContinuingEducation & Others \\
\hline $2(9 \%)$ & $2(9 \%)$ & $14(63.6 \%)$ & $8(36.3 \%)$ & $2(9 \%)$ \\
\hline
\end{tabular}

Source: The author.

parents/caregivers through changes in posture, utensils, volume, and food consistency was also used (16-17).

During this research, we retrieved 2 papers that introduced 2 alternative approaches. The first was the addition of continuing education through the use of a feeding tube and intermittent positive-pressure respirators in children and adolescents with chronic respiratory diseases (20). The second proposed olfactory stimulation with black pepper oil (21).

\section{CONCLUSION}

Even with the constant increase of the cerebral palsy population due to technological advances in medical treatments for pre-, peri-, and neonatal care, few studies include the (re)habilitation of these children in relation to treatment of oropharyngeal dysphagia. The present survey identified only 22 reports among 310 that referred to neurological diseases and disorders of swallowing that actually focused on speech therapy. Among the 22 articles retrieved, only $2(9 \%)$ were national, which reveals the limited concern of Brazilian researchers in investigating the efficiency of rehabilitation methods for oropharyngeal dysphagia in children with cerebral palsy.

\section{REFERENCES}

1. Bobath K. Uma base neurofisiológica para o tratamento da paralisia cerebral. 2. ed. São Paulo: Manole; 1984.

2. Mancini MC, Fiúza PM, RebeloJM, Magalhães LC, Coelho ZAC, Paixão ML, Gontijo APB, Fonseca ST. Comparação do desempenho de atividades funcionais em crianças com desenvolvimento normal e crianças com paralisia cerebral. Arq. Neuropsiquiatr, 2002; 60:446-452.

3. Paneth N, Hong T, Korzeniewski S. The descriptive epidemiology of cerebral palsy. Clin. Perinatol, 2006; 33: 251-267.

4. Geoorgos/Defnet. Disponível em http:// www.defnet.org.br/. Acesso em 15 out 2011.

5. Santini CS. - Disfagia neurogênica Em: Furkim AM, Santini CS: Disfagias Orofaringeas. $2^{a}$ ed. Rev., Atual. e Amp. São Paulo: Pró-fono, 2004. pp. 19-34.

6. Calis EA, Veugelers R, Sheppard JJ, Tibboel D, Evenhuis HM, Penning C. Dysphagia in children with severe generalized cerebral palsy and intellectual disability. Dev . Med. Child. Neurol, 2008; 50:625-630.

7. Silva AB, Piovesana AMSG, Barcelos IHK, Capellini SA. Evaluación clínica y videofluoroscópica de la deglutición en pacientes con parálisis cerebral tetraparésica espástica y atetósica. Rev. Neurol, 2006; 42:462-465.

8. Fitzgerald DA, Follett J, Asperen PP. Assessing and managing lung disease and sleep disordered breathing in children with cerebral palsy. Paediatr Respir Rev, 2009; 10:18-24.

9. Morales RC. Terapia de regulação orofacial: Conceito RCM. São Paulo: Memnon, 1999.

10. Furkim AM. O gerenciamento fonoaudiológico das disfagias orofaríngeas neurogênicas Em: Furkim AM, Santini CS: Disfagias Orofaríngeas. $2^{a}$ ed. Rev., Atual. e Amp. São Paulo: Pró-fono, 2004. pp. 229-258. 
11. Ismar HH. An autotherapeutic device assisting patients from drooling to articulated speech. Pediatr. Rehabil, 2005; 8:248-262

12. Silva RG. Reabilitação fonoaudiológica na disfagia orofaríngea neurogênica em adultos: a educação continuada como princípio Em: Filho, EDM, et al. Disfagia: Abordagem Multidisciplinar. $2^{\mathrm{a}}$ ed. amp. São Paulo: Frôntis Editorial, 1999. p. $145-152$

13. Limbrock GJ, Hesse A, Hoyer H. Castillo-Morales orofacial regulation therapy method in children with brain lesions. Fortsch. Kieferorthop, 1987; 48:355-359.

14. Limbrock GJ, Hoyer H, Scheying H. Drooling, chewing and swallowing dysfunctions in children with cerebral palsy: treatment according to Castillo-Morales. ASDC J. Dent. Child, 1990; 57:445-451.

15. Gisel EG. Interventions and outcomes for children with dysphagia. Dev. Disabil. Res. Rev, 2008; 14:165-173.

16. Silvério CC, Henrique CS. Indicadores da evolução do paciente com paralisia cerebral e disfagia orofaríngea após intervenção terapêutica. Rev Soc Bras Fonoaudiol, 2009; 14:381-386.
17. Silvério CC, Henrique CS. Paciente com paralisia cerebral coreoatetoide: evolução clínica pós-intervenção. Rev CEFAC, 2010; 250-256.

18. Olszewski J. Causes, diagnosis and treatment of neurogenic dysphagia as an interdisciplinary clinical problem. Otolaryngol Pol, 2006; 60:491-500.

19. Gisel EG, Tessier MJ, Lapierre G, Seidman E, Drouin E, Filion G. Feeding management of children with severe cerebral palsy and eating impairment: an exploratory study. Phys Occup Ther Pediatr, 2003; 23:19-44.

20. Kitazumi E. Care continuity for patients with cerebral palsy during transition from childhood to adulthood. Jpn J. Clin Med, 2010; 68:27-32.

21. Munakata M, Kobayashi K, Niisato-Nezu J, Tanaka S, Kakisaka Y, Ebihara T, Ebihara S, Haginoya K, Tsuchiya S, Onuma A. Olfactory stimulation using black pepper oil facilitates oral feeding in pediatric patients receiving longterm enteral nutrition. Tohoku J Exp Med, 2008; 214:327332. 